\title{
MÚLTIPLOS DO CATIVEIRO: \\ CASAMENTO, COMPADRIO E EXPERIÊNCIA COMUNITÁRIA NUMA PROPRIEDADE ESCRAVA NO GRÃO-PARÁ \\ $(1840-1870)^{*}$
}

Daniel Souza Barroso**

$\mathrm{P}$ or longo tempo, a escravidão negra na Amazônia representou uma zona de opacidade na historiografia brasileira. Uma ideia fortemente arraigada de que a economia das antigas capitania e província do Grão-Pará, basicamente extrativista, havia sido suportada pela mão de obra indígena e, posteriormente, pela mão de obra de retirantes nordestinos, acabou relegando outras atividades econômicas e formas de trabalho a um segundo plano e encobrindo, na historiografia, a sua importância no funcionamento e na dinâmica da economia amazônica. ${ }^{1}$ No entanto, como estudos um pouco mais recentes vêm demonstrando, os escravos negros não apenas figuraram, em determinadas conjunturas, enquanto uma parte expressiva da população paraense, como também

* Este artigo representa uma versão revisada e ampliada de parte do terceiro capítulo da dissertação de mestrado: "Casamento e compadrio em Belém nos meados do Oitocentos", defendida em abril de 2012, junto ao Programa de Pós-Graduação em História Social da Amazônia do IFCH-UFPA. $\mathrm{O}$ autor agradece ao professor Antonio Otaviano Vieira Junior pela orientação da pesquisa, bem como aos professores Carlos Bacellar e Cristina Cancela pelos comentários feitos por ocasião do Exame de Qualificação e de Defesa. Os agradecimentos se redobram ao parecerista da Afro-Ásia e aos professores José Flávio Motta, Cacilda Machado e Maria Luiza Andreazza pelas críticas tecidas a uma versão embrionária deste estudo, apresentada no IV Simpósio Nacional de História da População, realizado em Belém, entre 18 e 21 de outubro de 2011.

** Doutorando em História Econômica na Universidade de São Paulo. dsbarroso@usp.br

1 Sobre as linhas gerais desse debate, ver: Rafael Chambouleyron, "Escravos do Atlântico Equatorial: tráfico negreiro para o Estado do Maranhão e Pará (século XVII e início do século XVIII)", Revista Brasileira de História, v.26, n.52 (2006), pp.79-114. 
constituíram, até pelo menos os meados do século XIX, uma força produtiva de grande importância - principalmente para a agricultura e a pecuária no Grão-Pará. ${ }^{2}$

Muito embora esse quadro tenha sido (e, em alguma medida, continue sendo) matizado por novos estudos, a família escrava, em particular, permanece como um elemento ainda pouquíssimo explorado. Excetuando-se, aqui, alguns apontamentos feitos nos trabalhos de Luciana Marinho, ${ }^{3}$ Andréa Pastana ${ }^{4}$ e Walter Hawthorne, ${ }^{5}$ e, igualmente, em alguns dos nossos trabalhos, ${ }^{6}$ praticamente nada foi produzido a respeito dessa temática, que é de grande importância para o entendimento da demografia da escravidão no Grão-Pará oitocentista. ${ }^{7}$ Considerando-se que a província esteve, ao que tudo indica, um tanto quanto alheia ao tráfico interno de escravos nos meados do Oitocentos — não tendo sido ainda apresentadas evidências consistentes da entrada ou da saída de uma expressiva quantidade de cativos - , a família escrava, em sentido lato, ganha destaque por ter estado, muito provavelmente, no cerne dos mecanismos de reprodução demográfica dos cativos paraenses ao longo de grande parte do século XIX.

No esforço de ajudar a suprir esta lacuna e de matizar a compreensão acerca da família escrava no Grão-Pará oitocentista, o presente artigo tem como objetivo analisar as práticas de casamento e de compadrio dos cativos do Engenho Bom Intento, entre 1840 e 1870. Confrontando

José Maia Bezerra Neto, Escravidão negra no Grão-Pará (séculos XVII-XIX), Belém: Paka-Tatu, 2001.

3 Luciana Marinho Batista, "Demografia, família e resistência escrava no Grão-Pará (1850-1855)", in José Maia Bezerra Neto e Décio de Alencar Guzmán (orgs.), Terra Matura: historiografia e história social na Amazônia (Belém: Paka-Tatu, 2002), pp.207-30.

4 Andréa da Silva Pastana, "Em nome de Deus, Amém! Mulheres, escravos, famílias e heranças através dos testamentos em Belém do Grão-Pará na primeira metade do século XIX" (Dissertação de Mestrado, Universidade Federal do Pará, 2008).

5 Walter Hawthorne, From Africa to Brazil: Culture, Identity, and an Atlantic Slave Trade, 16001830, Cambridge: Cambridge University Press, 2010.

6 Daniel Souza Barroso, "Casamento e compadrio em Belém nos meados do Oitocentos" (Dissertação de Mestrado, Universidade Federal do Pará, 2012); Antonio Otaviano Vieira Junior e Daniel Souza Barroso, "Histórias de 'movimentos': embarcações e população portuguesas na Amazônia joanina", Revista Brasileira de Estudos de População, v.27, n.1 (2010), pp.193-210. Para um balanço da produção sobre a História da Família e a História da População no Pará, ver: Daniel Souza Barroso, "A historiografia das formas familiares e o desenvolvimento da Demografia Histórica no estado do Pará, Brasil (1970-2012)", in Anais do X Congresso da Associação de Demografia Histórica (Madrid: ADEH/CCHS-CSIC, 2013). 
essas práticas com as tendências apresentadas pelos escravos da cidade de Belém, e lançando mão do cruzamento entre os registros paroquiais de batismo e de casamento concernentes àquele plantel e o inventário post-mortem do proprietário do Engenho, ${ }^{8}$ analisamos como o casamento e o compadrio atuaram na conformação de uma comunidade escrava que transbordava os próprios limites do cativeiro, compreendendo escravos de outras propriedades, os forros e a população livre de Bujaru. O jogo de escalas que ora propomos possibilita-nos, por um lado, evidenciar as influências estruturais (e conjunturais) daquele período sobre uma realidade específica e, por outro lado, relativizar as tendências apresentadas pela população cativa de Belém no que diz respeito ao casamento e ao compadrio.

$\mathrm{O}$ artigo encontra-se estruturado em três seções. Na primeira delas, interessa-nos apresentar alguns aspectos gerais (localização, importância econômica e estrutura física) do Engenho Bom Intento, bem como parte dos mecanismos de reprodução e o perfil dos escravos dessa propriedade em função dos marcadores de gênero, geração e etnia. Na segunda seção, objetivamos examinar as práticas de casamento em si, com foco nas preferências matrimoniais, no perfil dos cativos que tiveram acesso ao casamento legítimo e, novamente, nos seus mecanismos de reprodução. Na última seção, a nossa reflexão incide sobre o compadrio, com a finalidade de entrevermos as estratégias que permearam a escolha dos padrinhos e a importância do parentesco espiritual na configuração da tessitura social existente no seio daquela comunidade escrava.

Centro de Memória da Amazônia (CMA/UFPA). Cartório Fabiliano Lobato (11 ${ }^{\mathrm{a}}$ Vara Cível). Inventários post-mortem, 1862, cx. 139. Autos cíveis de inventário post-mortem em que é inventariado Joaquim Antônio da Silva e inventariante, Januário Antônio da Silva. O inventário do proprietário do Engenho Bom Intento, onde também consta o traslado do seu testamento, apresenta a descrição das posses de Joaquim Antônio da Silva no Brasil. A sua propriedade escrava, tal como nos demais inventários paraenses da década de 1860 , foi arrolada pelo sexo (primeiro os homens e depois as mulheres), em ordem alfabética e de acordo com a geração (primeiros os escravos adultos e velhos, depois as crianças cativas). Ao não arrolar os escravos em associação com as suas respectivas famílias, o inventário inviabiliza o avanço na discussão de determinados aspectos a elas atinentes. De agora em diante, não citaremos mais o inventário em questão em notas de rodapé. Todas as citações indicadas no corpo do texto remetem à aludida referência. 


\section{O Engenho Bom Intento: plantel escravo, estrutura e cotidiano}

O Engenho Bom Intento, pertencente ao português Joaquim Antônio da Silva, estava localizado às margens do rio Guamá, na altura do Distrito de Bujaru (ver: Figura 1). Situava-se em um ambiente predominantemente rural, caracterizado pela presença de posseiros (ainda fruto das particularidades da colonização portuguesa nessa região) e pela marcante concentração de cativos. ${ }^{9}$ Com cerca de 250 léguas de extensão e delimitada pelas terras de Manoel Joaquim Pinto de Paiva e de Pedro Batista de Sousa Leal Aranha, a propriedade possuía, no início dos anos de 1860: uma casa de varanda; um oratório; um engenho; plantações de cana e de arroz, animais diversos e ranchos para moradia dos seus 157 escravos. Sob a administração direta de Januário Antônio da Silva, irmão de Joaquim, o Engenho Bom Intento dedicava-se à extração da madeira e à produção do arroz e de derivados da cana.

No engenho não havia senzala, e os escravos habitavam em "ranchos" próprios para sua moradia. Esses "ranchos" nada mais eram do que cabanas rústicas feitas de material leve, como a palha ou ramos de árvore. Foram, ao lado da casa principal, morada do administrador do Bom Intento, Januário Antônio da Silva, o único tipo de moradia especificado no inventário de Joaquim. Nesse documento, também não encontramos qualquer referência que pudesse indicar a presença de pessoas livres morando na propriedade. Na descrição dos "ranchos", que poderiam servir de moradia a esses indivíduos, especificou-se que eles se destinavam somente aos cativos. Por sua vez, a descrição da casa principal também não faz qualquer alusão a espaços destinados para uma população livre, que não ao próprio Januário.

\footnotetext{
Sobre a importância econômica local do Engenho Bom Intento, ver: Edna Maria Ramos de Castro, "Terras de preto entre igarapés e rios", in Anais do II Encontro da Associação Nacional de Pós-Graduação e Pesquisa em Ambiente e Sociedade (São Paulo: Associação Nacional de Pós-Graduação e Pesquisa em Ambiente e Sociedade, 2004). Acerca das características da colonização portuguesa na região do Baixo Tocantins, cf.: Maria de Nazaré Ângelo-Menezes, "Une histoire sociale des systèmes agraires dans la vallé du Tocantins, État du Pará, Brésil: colonisation européenne dans la deuxième moitié du XVIII siècle et la première moitié du XIX siècle" (Tese de Doutorado, École des Hautes Études en Sciences Sociales, 1998).
} 


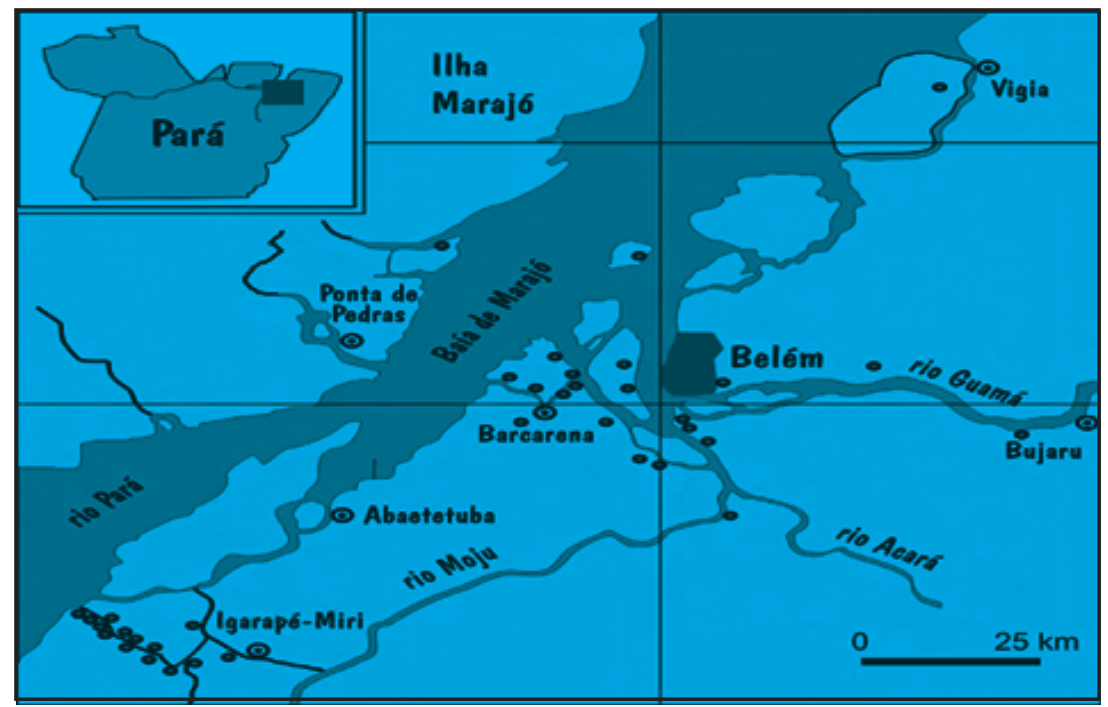

Figura 1 - Engenhos no Estuário Amazônico

Fonte: Fernando Luiz Tavares Marques, "Modelo da agroindústria canavieira colonial no estuário amazônico: estudo arqueológico de engenhos dos séculos XVIII e XIX" (Tese de Doutorado, Pontifícia Universidade Católica do Rio Grande do Sul, 2004), p.XXIX.

Se a presença de pessoas livres morando no Engenho Bom Intento é incerta, as fontes permitem-nos assegurar, por outro lado, que a interação entre os escravos dessa propriedade e as populações livre e forra que moravam na região era relativamente contínua, assim como a sua interação com os cativos de outras propriedades. Isso porque, em face da presença ainda pouco estruturada e organizada da Igreja em Bujaru, o oratório e, anos mais tarde, a capela do Bom Intento atuaram como espaços onde se realizavam as cerimônias de batismo e casamento de grande parte da população local — e não apenas dos escravos ou dos proprietários do engenho, como poderíamos imaginar à primeira vista. Em verdade, na propriedade realizavam-se cerimônias coletivas que reuniam indivíduos das mais distintas condições sociais: de uma população ainda submetida ao regime do cativeiro ou dele recém-egressa, aos mais poderosos escravistas da Zona Guajarina, como os já mencionados Manoel Joaquim Pinto de Paiva e Pedro Leal Aranha. 
Essa característica específica do Engenho Bom Intento impunha, aos eventos ocorridos na propriedade, um atributo capaz de particularizar os parâmetros de interação social dos seus escravos. A abertura à sociedade de Bujaru, ao mesmo tempo em que ajudava a sedimentar uma base clientelista de poder local para Januário Antônio da Silva em relação a uma população livre e pobre e, especialmente, em relação aos demais escravistas da região que faziam uso daquele espaço, ${ }^{10}$ acabava, também, por inscrever os cativos em um circuito sem dúvida ainda mais amplo e complexo de sociabilidades, que não se cingia às relações essencialmente endógenas ao ambiente do Engenho Bom Intento - i. é, às relações experimentadas pelos escravos entre si e com o seu senhor de fato, Januário Antônio da Silva.

Todavia, ainda que a ocorrência dos ritos batismais e nupciais nessa propriedade tenha engendrado ocasiões importantes para a interação social dos múltiplos segmentos que compunham a população de Bujaru, a sua realização não deixou de satisfazer a uma distinção hierárquica. Em alguns dias, aconteciam separadamente os batizados e os casamentos de pessoas de uma condição social mais elevada — algumas delas, mais próximas do administrador do Engenho. Envolviam, a título de exemplo, os familiares de alguns dos proprietários das terras vizinhas ao Bom Intento que, por vezes, tinham Januário como padrinho de batismo ou como testemunha de casamento. Nos outros dias, era a vez dos cativos do Engenho Bom Intento, dos de propriedades vizinhas e da população livre da região. Evidentemente, toda essa movimentação no Engenho não passaria despercebida por Januário Antônio da Silva. A nosso ver, seria irreal supormos que fizessem uso do oratório ou da capela do Bom Intento indivíduos cujas presenças suas ou dos seus senhores desgostassem Januário.

Mais numerosas e corriqueiras, as cerimônias coletivas de batizado e de casamento do segundo grupo (escravos do engenho, de demais proprietários e a população livre da região) apresentavam uma sazonalidade característica, por certo influenciada pela dinâmica produtiva e

10 Na Colônia, as capelas tiveram um papel importante no processo de ocupação de determinadas regiões. Em São Paulo, por exemplo, cada bairro desenvolveu-se a partir da construção de uma capela, prática que criava uma base de poder clientelista para quem as edificava. Elizabeth Kuznesof. "A família na sociedade brasileira: parentesco, clientelismo e estrutura social (São Paulo, 1700-1880)", Revista Brasileira de História, v.9, n.18 (1988/1989), p.41. 
econômica do Engenho Bom Intento. Como boa parte dos engenhos do estuário amazônico, o Bom Intento tinha as águas das marés e das chuvas como força motriz. Indícios arqueológicos têm ajudado a esclarecer a lógica desse mecanismo. Muitas vezes situados à margem de rios ou igarapés caudalosos, alguns engenhos da Amazônia possuíam um complexo sistema compartimentado de canais que os punha para funcionar. ${ }^{11}$ Embora se apropriassem ainda da pluviosidade, eram as águas das marés que concebiam, com efeito, o seu funcionamento; quanto mais altas as marés, maior seria, consequentemente, a produtividade desses engenhos.

Considerando-se que, na região de Bujaru, o período de maior maré vai de outubro a abril ou maio do ano seguinte, é perfeitamente compreensível a aglutinação de cerimônias entre junho e setembro. Deixava-se para se realizar os batizados e os casamentos no período em que o engenho era menos produtivo. Nesse intervalo menos fecundo na produção do arroz e dos derivados da cana, a predileção por determinados meses e dias para a realização das cerimônias poderia ainda estar relacionada com os períodos das visitas pastorais ao Engenho do Bom Intento, assim como à própria organização do trabalho dos escravos no decorrer das semanas, dos meses e dos anos.

A propriedade não se destacava, entretanto, apenas como um local para os batismos e casamentos das populações livre e escrava da região, mas sobressaía-se, especialmente, como uma importante unidade produtiva na Zona Guajarina. Em meio aos demais estabelecimentos agrícolas e manufatureiros da região de Bujaru, cuja dinâmica econômica era suportada, em grande medida, pelo escravismo, o Engenho Bom Intento sobrelevava-se por toda a sua expressividade econômica e grande posse de cativos. ${ }^{12}$ Formava, ao lado de outros engenhos, sítios e fazendas, a paisagem característica daquela região, que contrastava com todo um universo de pequenos sitiantes que romperam "com a tendência de monocultivo e ordenaram um sistema de policultivo (mandioca, arroz, milho, feijão, algodão, café e outros) em pequenas extensões de terra

\footnotetext{
11 Fernando Luiz Tavares Marques, "Modelo da agroindústria canavieira colonial no estuário amazônico: estudo arqueológico de engenhos dos séculos XVIII e XIX" (Tese de Doutorado, Pontifícia Universidade Católica do Rio Grande do Sul, 2004).

12 Castro, "Terras de preto", p.11.
} 
com tendência à dispersão e que [...] [mantinham] vínculos regulares com o mercado". ${ }^{13}$

No limiar da década de 1860, quando da feitura do inventário postmortem de Joaquim Antônio da Silva, a propriedade escrava do Engenho Bom Intento era composta por 157 cativos, dos quais 15 foram alforriados pelas disposições testamentárias do português. Contextualmente, tratava-se de uma propriedade de grandes proporções, porém, havia poucos escravos em idade produtiva, um número pequeno de especializados em algum ofício e uma quantidade razoável de cativos acometidos por moléstias ou problemas físicos. Esses elementos tinham, decerto, implicações diretas na produtividade econômica do Bom Intento e poderiam condicionar, de múltiplas formas, os arranjos matrimoniais e as escolhas dos compadres no seio daquela comunidade escrava. Mas, qual era, afinal, o perfil dos escravos do Engenho Bom Intento? Havia, na propriedade, mais homens ou mulheres? Jovens ou velhos? Crioulos ou africanos?

Dos 142 escravos remanescentes no Engenho, 65 eram do sexo masculino e 77 do feminino, perfazendo uma razão de masculinidade geral de 84,4 . Trata-se de uma razão que pode ser considerada relativamente baixa, principalmente tendo em vista a dimensão da propriedade, a sua localização em um ambiente caracteristicamente rural e a sua principal atividade econômica; mas que condizia com a razão de masculinidade geral dos escravos da chamada Zona Guajarina - macrorregião em que se encontrava o Engenho Bom Intento. ${ }^{14}$ Ao que parece, mais do que uma

13 Rosa Elizabeth Acevedo Marin, “Camponeses, donos de engenhos e escravos na região do Acará nos séculos XVIII e XIX”, Papers do NAEA, v.153 (2000), pp.1-26.

14 O Recenseamento de 1872 indica, para a população escrava de Santana de Bujaru, uma razão de sexo na casa dos 90 . Além disso, evidencia também uma representativa quantidade de escravos jovens, sendo a aglutinação de velhos uma particularidade do Engenho Bom Intento. Aparentemente, esse perfil com um maior número de mulheres em idade adulta pode ter sido a tônica das posses de escravos do Grão-Pará nos meados do século XIX, como pôde verificar Luciana Marinho em sua pesquisa. Se, de fato, isso estiver correto, o perfil dos plantéis da província diferia-se dos seus correspondentes, por exemplo, no agreste e no sertão de Pernambuco ou na zona rural da cidade de São Paulo, no mesmo período. A respeito dessas realidades, ver: Luciana Marinho Batista, "Muito além dos seringais: elites, fortunas e hierarquias no Grão-Pará, c.1850-c.1870" (Dissertação de Mestrado, Universidade Federal do Rio de Janeiro, 2004); Zélia Cardoso de Mello, "Os escravos nos inventários paulistanos da segunda metade do século XIX”, in Antônio Emílio Muniz Barreto (org.), História Econômica: ensaios (São Paulo: IPE/ USP, 1983), pp.59-104; Flávio Rabelo Versiani e José Raimundo Oliveira Vergolino, "Posse de escravos e estrutura da riqueza no agreste e sertão de Pernambuco: 1777-1887", Estudos Econômicos, v.33, n.2 (2003), pp.353-93. 
70 ou $\mathrm{m}$ ais anos

65-69 anos

60-64 anos

55-59 anos

$50-54$ anos

45-49 anos

40-44 anos

35-39 anos

30-34 anos

25-29 anos

20-24 anos

15-19 anos

10-14 anos

5-9 anos

0-4 anos

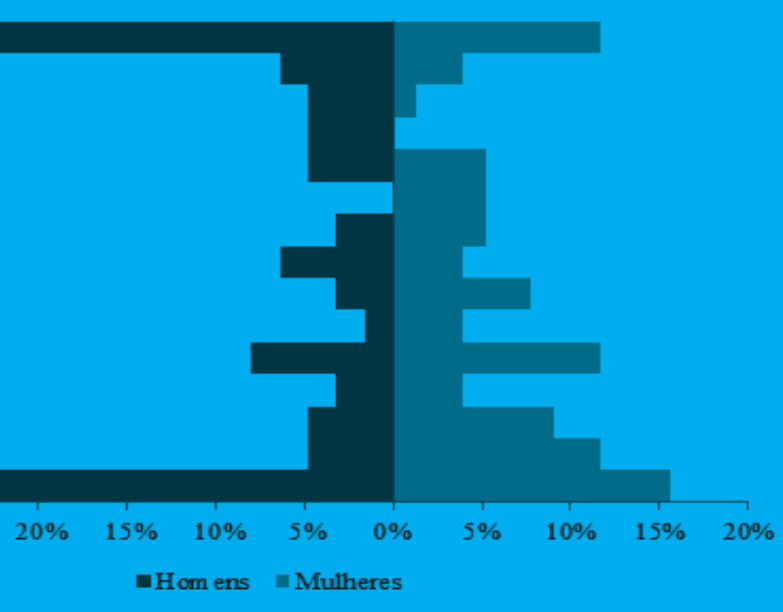

Gráfico 1 - Pirâmide sexo-etária dos escravos do Engenho Bom Intento

Fonte: Inventário post-mortem de Joaquim Antônio da Silva.

possível estratégia de composição de plantel referente a um caso específico, a elevada representatividade das mulheres na população escrava do Engenho Bom Intento, em particular, e na macrorregião onde estava inscrita a propriedade, em geral, é um indicativo da importância que a reprodução endógena dos cativos possuía, provavelmente já há algum tempo, para a manutenção da escravidão no Grão-Pará.

Em relação ao Engenho Bom Intento, o impacto dessa reprodução se torna ainda mais claro ao considerarmos a estrutura etária dos seus cativos. A pirâmide sexo-etária deste grupo (Gráfico 1) evidencia tanto entre os homens, quanto entre as mulheres, uma concentração nas idades mais altas e mais baixas. Se tomarmos como parâmetro de escravos jovens os menores de 15 e de escravos velhos os maiores de 50 anos, ${ }^{15}$ temos um quadro em que cerca de 70\% (46) dos homens e 55\% (43) das mulheres da propriedade eram jovens ou velhos - segmento em que se incluíam

15 A classificação dos escravos acima dos 50 anos como velhos foi proposta por José Flávio Motta para o caso da província de São Paulo. Em termos produtivos e tendo em vista as características particulares da escravidão na Amazônia, é possível que esse patamar tenda a ser majorado. De toda forma, neste trabalho, adotamos como parâmetro a classificação proposta pelo autor. Ver: José Flávio Motta, “O tráfico de escravos velhos (Província de São Paulo, 1861-1887)", História: Questões \& Debates, v.52 (2010), pp.41-73. 
todos os cativos africanos presentes e que era constituído, notadamente, por escravos com mais de 70 anos. Muito embora essa concentração possa ser, em alguma medida, desdobramento de uma evasão de cativos em idade adulta — aspecto ao qual nos ateremos mais adiante - , a alta natalidade e a baixa mortalidade sugeridas pelo desenho do Gráfico 1 levam-nos a conjecturar a incidência de um ocasional crescimento natural positivo entre os escravos dessa propriedade.

A alta natalidade que possivelmente permeou a dinâmica demográfica dos escravos do Engenho Bom Intento pode ter sido favorecida pelo excedente de mulheres em idade reprodutiva existente na propriedade. Entre os escravos em idade adulta (15-49 anos), existia uma proporção de duas mulheres para cada homem. Não obstante a sua presença em maior número, as cativas do Bom Intento ainda apresentavam uma elevada fecundidade, evidenciada pela expressiva razão crianças/mulheres de 1.187,5 — índice comparável às suas correspondentes de outras regiões do Brasil oitocentista que, a exemplo do Grão-Pará, dependiam em muito da reprodução endógena dos escravos. ${ }^{16}$ No entanto, essas altas natalidade e fecundidade dizem respeito, fundamentalmente, ao grande número de crianças e de jovens no engenho. O que explicaria, por outro lado, o número pouco expressivo de cativos em idade adulta e a grande quantidade de velhos nessa propriedade?

No que respeita à compreensão da pouca expressividade dos escravos em idade adulta no Engenho Bom Intento, o recorte de gênero é importante na medida em que nos possibilita relativizar a distribuição dos cativos de acordo com os segmentos etários. Posto que a razão de masculinidade geral dos seus escravos fosse de 84,4 - um índice que aponta para uma predominância feminina no plantel —, existiam grandes

16 A razão crianças/mulheres é tomada como um indicativo da fecundidade, sendo bastante utilizada em trabalhos sobre a escravidão que tenham como fonte as listas nominativas ou os inventários post-mortem. A razão remete-se ao número de mulheres em idade reprodutiva (15-49 anos) existente para o número de crianças (0-9 anos), vezes 1.000. As faixas etárias das mulheres em idade reprodutiva e das crianças variam de pesquisa para pesquisa. Em seu estudo sobre Mariana, Heló́sa Maria Teixeira verificou um aumento na razão crianças/mulheres entre o final da década de 1850 e o início dos anos 1860, provavelmente decorrente da proibição definitiva do tráfico atlântico. Nesse período, os planteis com mais de 20 escravos apresentavam também uma alta razão crianças-mulheres, na casa dos 1.300, o mesmo patamar verificado em relação ao sul dos Estados Unidos. Heloísa Maria Teixeira, "Família escrava, sua estabilidade e reprodução em Mariana, 1850-1888”, Afro-Ásia, v.28 (2002) pp.179-220. 
oscilações entre as razões de masculinidade de cada segmento. Entre os jovens (0-14 anos), a razão era de 71,4; entre os adultos (15-49 anos), de 50; e, entre os velhos (50 ou mais anos), de 164,7. Em outras palavras, não somente havia poucos cativos em idade adulta na propriedade (ver Gráfico 1), como também havia uma acentuada prevalência feminina nesse segmento etário, característica que se efetivava de maneira um pouco mais tímida entre os jovens e que se infletia em relação aos velhos.

Não desconsiderando o possível — mas improvável — impacto de uma mortalidade diferenciada em função do gênero, a significativa predominância das mulheres nos dois primeiros segmentos e, dos homens, no último segmento etário, pode ser sugestiva de uma evasão de cativos do sexo masculino para outras regiões do Grão-Pará ou, mesmo, para outras províncias. Levando-se em consideração que a importação de escravos, por parte do sudeste cafeeiro, priorizava cativos do sexo masculino e em idade produtiva, ${ }^{17}$ um possível movimento de refluxo de escravos do Engenho Bom Intento poderia justificar a pouca quantidade de homens adultos na propriedade, já no limiar da década de 1860. Hipótese que ganha ainda mais força pelo fato de os meados do século XIX terem representado, no Brasil, um contexto marcado pela intensificação no controle e a extinção definitiva do tráfico atlântico. ${ }^{18}$

Essa posição desfavorável do Engenho Bom Intento perante o tráfico de escravos parece ter sido anterior ao período em questão; não necessariamente no que concerne a um provável refluxo de cativos, mas, sobretudo, no que concerne a uma possível dificuldade em repor eventuais perdas a partir do tráfico. Um indicativo, nesse sentido, é a presença rarefeita de cativos africanos na propriedade. No início da década de 1860, quando do inventário de Joaquim Antônio da Silva, havia apenas cinco escravos (um homem e quatro mulheres) de origem africana no engenho. Deles, a mais nova, a cativa Catarina Angola, tinha cerca de 50 anos de idade, e todos

17 Cf.: Robert W. Slenes, "The Demography and Economics of Brazilian Slavery, 1850-1888" (PhD. Dissertation in History, Stanford University, 1976). Acerca do debate historiográfico em torno do tráfico interprovincial de escravos, ver: José Flávio Motta, "Historiografia e tráfico interno de escravos no Brasil", in Escravos daqui, dali e de mais além: o tráfico interno de cativos na expansão cafeeira paulista (São Paulo: Alameda, 2012), pp.61-101.

18 Ver: Jaime Rodrigues, $O$ infame comércio: propostas e experiências no final do tráfico de africanos para o Brasil (1800-1850), Campinas: Editora da Unicamp/CECULT, 2000. 
os demais já possuíam 70 ou mais anos. Considerando-se que os cativos africanos eram comprados ordinariamente em idade produtiva, é possível que os últimos escravos da África tenham aportado na propriedade até o alvorecer dos anos de 1830, em um dos últimos navios negreiros destinados ao Grão-Pará. ${ }^{19}$ E que, desde então, a manutenção dessa posse de escravos tenha vindo a depender da sua reprodução endógena, nos termos em que analisamos nas últimas páginas.

Mas, cabe-nos salientar que, fossem eles crioulos ou africanos, a maciça presença de escravos velhos no Engenho Bom Intento não é atinente apenas ao comportamento da propriedade em torno do tráfico de cativos e à baixa mortalidade sugerida no Gráfico 1. A despeito disso e por mais que o perfil do seu plantel comungasse, em função do gênero e da geração, com o perfil sexo-etário dos cativos da chamada Zona Guajarina, não podemos deixar de vislumbrar a estrutura etária dos escravos dessa propriedade sob a sua ótica particular — intimamente relacionada com as trajetórias de vida de Joaquim e de Januário Antônio da Silva. O estado envelhecido de alguns cativos e a diminuta quantidade de escravos em idade adulta não podem ser lidos, portanto, apenas à luz de um enquadramento contextual, mas, igualmente, como aspectos imbricados à trajetória e ao ciclo de vida do proprietário do Engenho Bom Intento.

Acreditamos que o estado envelhecido de parte dos escravos fosse decorrente, dentre outros fatores já citados, do próprio processo de envelhecimento de Joaquim Antônio da Silva. ${ }^{20}$ Ao falecer em 02 de julho de 1861, Joaquim tinha 77 anos de idade, doze a mais do que Januário. ${ }^{21}$

19 De acordo com Vicente Salles, o último navio negreiro aportou no Pará em 1834, rompendo com o comércio direto com as praças da África. Nos anos seguintes, ainda segundo o autor, a importação de cativos de outras províncias brasileiras continuou, estimulada pela isenção de direitos fiscais, até as vésperas da assinatura da Lei Áurea. Vicente Salles, O negro no Pará sob o regime da escravidão, Belém: Instituto de Artes do Pará, 2005 [1971], p.76.

20 Para um aprofundamento na discussão sobre a relação entre os ciclos de vida dos escravos e dos seus senhores, ver: Iraci del Nero da Costa, "Nota sobre ciclo de vida e posse de escravos", in Francisco Vidal Luna et al. (orgs.), O escravismo em São Paulo e Minas Gerais (São Paulo: EDUSP/ Imprensa Oficial do Estado de São Paulo, 2010), pp.441-7.

21 Os registros de batismo de Joaquim e Januário Antônio da Silva, constantes no acervo do Arquivo Nacional da Torre do Tombo, em Portugal, nos foram gentilmente cedidos pelo Prof. Dr. João dos Santos Ramalho Cosme, a quem agradecemos de antemão. Por meio deles sabemos que os irmãos, filhos legítimos de José Joaquim Figueiredo e Maria Teodora, foram batizados na freguesia do Castelo, Sertã, na cidade de Lisboa. O primeiro no dia 04 de março de 1785 e o segundo, no dia 02 de abril de 1797 . No mesmo acervo, consta também o registro de óbito 
Eram, ambos, da mesma geração que boa parte dos homens e mulheres escravizados sob sua posse. Nessa perspectiva, o ciclo de vida dos cativos acompanhara, então, o ciclo de vida do seu proprietário. Com o avançar da idade e, especialmente, com a sua partida definitiva rumo a Lisboa em 1834 (deixando, a partir de então, a administração do Engenho Bom Intento aos cuidados de Januário), é possível que a capacidade de Joaquim em renovar a sua propriedade tenha se amainado gradualmente, e não apenas por questões de ordem econômica. Devemos considerar, por outro lado, que Joaquim Antônio da Silva era viúvo e não tinha filhos, o que pode ter ocasionado, por sua parte, uma perda de interesse na referida renovação. ${ }^{22}$ Se isso estiver certo, a manutenção do seu plantel teria passado a depender, ainda mais, da sua própria reprodução.

\section{Fortalecendo um grupo: o casamento}

A alta dependência criada em relação à reprodução endógena dos escravos não parece ter sido peculiaridade do Engenho Bom Intento. O estado da arte da escravidão na Amazônia, nos meados do Oitocentos, praticamente condicionava a manutenção da escravatura na região, à sua própria reprodução. Com a rearticulação do escravismo brasileiro, levada a cabo pela Lei Eusébio de Queirós, e a incapacidade das elites locais em proceder a uma renovação efetiva da população cativa da província do Grão-Pará por intermédio do tráfico interprovincial, fazia-se necessário incentivar sua reprodução demográfica. Uma primeira resposta a essa rearticulação, muito provavelmente orquestrada por parte dos escravistas paraenses, pode ser notada pelo aumento quase que instantâneo da taxa bruta de nupcialidade

de Joaquim. "Proprietário" e viúvo de d. Maria da Assunção, ele faleceu aos 77 anos de idade no dia 02 de julho de 1861, recebendo todos os sacramentos. Arquivo Nacional da Torre do Tombo (ANTT) Paroquiais do Distrito de Castelo Branco, Freguesia do Castelo, Sertã, Baptismos, Livro 05, fl. 104 (v); Arquivo Nacional da Torre do Tombo (ANTT) Paroquiais do Distrito de Castelo Branco, Freguesia do Castelo, Sertã, Baptismos, Livro 06, fl. 64; Arquivo Nacional da Torre do Tombo (ANTT) Paroquiais, Freguesia Nossa Senhora da Lapa, Óbitos, Livro 04, fl. 264(v), Reg. v.59.

22 Robert W. Slenes verificou que, em situações semelhantes à de Joaquim Antônio da Silva, alguns proprietários não apenas deixavam de renovar as suas propriedades, como também acabavam libertando os seus cativos ao final da vida. Robert W. Slenes, "Senhores e subalternos no oeste paulista", in Luiz Felipe de Alencastro (org.), História da vida privada no Brasil: Império, a corte e a modernidade nacional (São Paulo: Companhia das Letras, 2010 [1997]), pp.266-7. 
dos cativos de Belém ocorrido naquele período. ${ }^{23}$ Sendo o matrimônio apreendido como uma instituição promotora da fecundidade, na leitura dos proprietários, estimular os casamentos dos escravos significava, por conseguinte, fomentar a reprodução biológica desse grupo.

Não obstante o aumento da sua nupcialidade, os casamentos entre os cativos paraenses ocorridos nas décadas de 1840, 1850 e 1860 , apresentavam algumas características gerais que gostaríamos de pontuar. Em um estudo anterior, ${ }^{24}$ por meio da análise de todos os registros de casamento de escravos produzidos na paróquia da Sé de Belém naquelas décadas, observamos naquele grupo um comportamento matrimonial caracterizado (1) pelas endogamias social e metaétnica, (2) pela baixa incidência de enlaces em segundas ou mais núpcias, e (3) por uma acentuada prevalência de casamentos intraplantéis. Além disso, verificamos que, em relação a esta última característica, existia uma diferença comportamental entre os cativos que moravam no núcleo urbano central de Belém — demarcado por um ambiente urbano, de pequenas posses - e aqueles que habitavam as regiões mais afastadas, marcadamente rurais e com uma elevada concentração de cativos, vide a Zona Guajarina. Nestes espaços, bem mais do que naquele, os casamentos entre escravos de uma mesma propriedade eram como uma prática universalizada, um padrão de comportamento raramente desviado. ${ }^{25}$

Em meio a todos os registros de matrimônio pesquisados para os anos de 1840 a 1870 , deparamo-nos com 25 assentos que envolviam

23 A taxa bruta de nupcialidade da população cativa de Belém apresentou um expressivo crescimento entre o final da década de 1840 e o limiar dos anos 1850, com uma tendência à estabilização a partir do início dos anos 1860. Em 1848, essa taxa foi de 0,93; em 1854, 3; em 1862, 1,66; em 1872, 1,72. Barroso, "Casamento e compadrio em Belém", p.49.

24 Barroso, "Casamento e compadrio em Belém", pp.59-66.

25 Há um consenso na historiografia sobre a influência da dimensão dos plantéis no comportamento matrimonial dos escravos. Em linhas gerais, tem-se verificado que ao passo em que nas menores propriedades a ocorrência de casamentos interplantéis era mais frequente, nas maiores propriedades acontecia justamente o inverso. Entende-se que os maiores plantéis ofertavam aos escravos um maior rol de opções de nubentes em seu próprio ambiente, sublinhando a maior efetividade dos casamentos intraplantéis. Evidentemente, o debate acerca do casamento de cativos compreende ainda diversas outras condicionantes, que em alguma medida buscamos considerar ao longo do presente artigo. Para uma visão mais geral a respeito dessa historiografia, cf. dentre outros: José Flávio Motta, "A família escrava na historiografia brasileira: os últimos 25 anos", in Eni de Mesquita Samara (org.), Historiografia brasileira em debate: olhares, recortes e tendências (São Paulo: Humanitas, 2002), pp.235-54. 
cativos da propriedade no papel de nubentes - isso sem considerarmos a existência de subregistros e os eventos nos quais eles atuaram como testemunhas de matrimônio. Por mais que se trate de um quantitativo que não autoriza o delineamento de padrões de comportamento, esses registros permitem-nos perceber, como um ponto de partida, a correlação existente entre as práticas de casamento daquela escravaria, e as tendências de casamento apresentadas pelos escravos das regiões mais afastadas de Belém, sobretudo da Zona Guajarina. Os enlaces matrimoniais entre os cativos de Joaquim Antônio da Silva não eram apenas direcionados pela endogamia social e metaétnica (esta última, nos casos em que os poucos africanos sob sua propriedade contraíram núpcias); ao mesmo passo, todos os casamentos se germinaram no ambiente do plantel, unindo dois escravos do Engenho Bom Intento, a exemplo do matrimônio entre Domingos e Juliana.

No dia 19 de agosto de 1841, no oratório do Engenho Bom Intento, o cativo Domingos Dias, filho de pais incógnitos, casou-se com Juliana Joaquina, sua companheira de cativeiro e filha legítima dos também escravos Joaquim e Joaquina Maria. A cerimônia teve como testemunhas os escravos José e Joana Batista, também pertencentes a essa propriedade. ${ }^{26} \mathrm{~A}$ partir do registro do casamento entre Domingos e Juliana, podemos apreender apenas que, naquela distante quinta-feira, contraíram matrimônio, em primeiras núpcias, dois cativos de um mesmo senhor; ele, filho ilegítimo e, ela, de condição legítima. Somos levados a crer, ao mesmo passo, que Domingos e Juliana eram de origem crioula e que a família dela já se encontrava estabelecida no Engenho há algum tempo, pois os seus pais eram casados. Porém, ao cotejarmos esse assento com o inventário de Joaquim Antônio da Silva, abrem-se outras instigantes possibilidades de análise.

Uma primeira possibilidade diz respeito à idade de casamento dos escravos do Engenho Bom Intento. Por meio do cruzamento entre os registros de matrimônio dos cativos e o inventário do proprietário, constatamos que, à época do enlace, Domingos possuía entre 40 e 50 anos. Já Juliana, provavelmente falecida, não chegou a ser arrolada nos bens de Joaquim Antônio da Silva, muito embora a idade de sua mãe possa

${ }^{26}$ Cúria Metropolitana de Belém (CMB). Livro I de Registros de Casamento do Curato da Sé, p.05(v). 
nos servir de parâmetro. Se Joaquina Maria tinha em torno de 50 anos à altura do casamento de sua filha, é patente que Juliana era mais jovem que seu noivo. Uma segunda possibilidade de análise atém-se à prática de um ofício especializado por parte dos cativos que contraíram matrimônio. O inventário nos informa que Domingos era carapina, uma espécie de carpinteiro de construções rurais diversas de grande importância para o funcionamento dos engenhos. Além disso, o inventário permite-nos abonar a origem crioula de Domingos e Juliana. De que forma esses três fatores poderiam condicionar as práticas de casamento dos cativos do Engenho Bom Intento? A diferença etária entre os cônjuges e o exercício de um ofício especializado eram particularidades de Domingos e Juliana, ou características gerais dos escravos que se casaram na propriedade?

Atentemos, primeiro, para as idades de matrimônio. Assim como Domingos Dias, boa parte dos cativos homens do engenho casava-se em idades superiores aos 40 anos. Sete em cada dez nubentes haviam ultrapassado esse patamar ao terem acesso ao primeiro casamento; inclusive, a maioria deles já possuía 50 ou mesmo 60 anos na ocasião. Os outros três em cada dez nubentes que se casaram com menos de 40 anos o fizeram em idades que variavam, mas que nunca foram inferiores aos 20 anos. Comparativamente, as idades das mulheres escravas da propriedade na altura do primeiro matrimônio eram menores/mais baixas, todavia mais diversificadas, sugerindo, em alguns casos, uma preocupação com o seu período fértil. ${ }^{27}$ Vitória e Venância, as cativas mais jovens a se casarem

27 As escravas do Engenho Bom Intento davam à luz em idades que variavam, geralmente, dos 15 aos 30 anos. A ausência de registros de óbito e a possível ocorrência de sub-registros de batismo, não nos autorizam a medir com precisão os intervalos genésicos dessas mulheres. Feitas as devidas ressalvas, encontramos um intervalo de dois a três anos entre cada nascimento. Ainda que pesem outros fatores, o intervalo encontrado provavelmente estava relacionado a um maior ou menor tempo de lactância, e, igualmente, às idades das mães; observamos que quanto mais velhas as mulheres, maior o intervalo apresentado entre um nascimento e o outro. Cabe-nos ressaltar, ainda, que a estimativa encontrada em relação àquela escravaria assemelha-se aos intervalos genésicos verificados para as populações escravas de outras regiões da América Latina. Aisnara Diaz e María Fuentes se depararam com um intervalo médio de dois anos entre as cativas de Santiago de Cuba. Por sua vez, Manolo Florentino e José Roberto Góes encontraram um intervalo médio de três anos entre as crioulas do plantel de Manoel de Aguiar, em Bananal, São Paulo. Acerca dessas diferentes realidades, cf.: Aisnara Perera Díaz e María Fuentes, "Esclavitud, familia y parroquia en Cuba. Otra mirada desde la microhistoria", Revista Mexicana de Sociología, v.68, n.1 (2006), pp.137-80; Manolo Garcia Florentino e José Roberto Góes, “A reconstituição de famílias escravas: parentesco e família entre os cativos de Manoel de Aguiar Vallim (1872)", Anales del II Congreso de la Asociación Latinoamericana de Población (Guadalajara, ALAP, 2006). 
no Engenho Bom Intento, tinham entre 15 e 20 anos de idade. Joaquina Maria Bibiana, a mais velha, possuía aproximadamente 60 anos quando do seu matrimônio em segundas núpcias.

Nesse sentido, havia na propriedade uma tendência de os homens casarem com mais, e as mulheres com menos idade, prática que implicava, consequentemente, uma diferença etária entre os cônjuges, que oscilava muito mais em função das idades das nubentes — variáveis do que das idades dos nubentes - relativamente mais constantes. Essa característica sugere que a articulação dos enlaces no plantel perpassava por um evidente recorte geracional e de gênero, como no matrimônio entre Domingos e Juliana. Via de regra, os homens entravam mais tarde, entretanto permaneciam por mais tempo no mercado matrimonial; ao contrário das mulheres, que poderiam ter acesso ao casamento tão logo estivessem na sua idade fértil, mas dele saíam mais cedo.

Não foi, contudo, somente em relação à idade ao casar que o enlace entre Domingos e Juliana se aproximou das práticas de casamento no Bom Intento. A exemplo do carapina, uma parcela não pouco expressiva dos escravos da propriedade que tiveram acesso ao matrimônio, exercia um ofício. Para um cativo, ser carapina, pedreiro ou ferreiro significava ser uma mão de obra especializada, o que exprimia a sua valorização não apenas em termos econômicos, ${ }^{28}$ mas, talvez principalmente, no âmbito das relações sociais estabelecidas no seio de uma dada comunidade escrava, tendo em vista a centralidade que a vida material possuía na experiência social dos cativos. ${ }^{29}$

$\mathrm{O}$ terceiro aspecto que, ainda que em menor medida, poderia in-

${ }_{28}$ Os critérios de avaliação dos escravos dessa propriedade foram praticamente os mesmos adotados nos inventários paulistanos da segunda metade do século XIX, pesquisados por Zélia Cardoso de Mello. Notamos que havia uma relação entre o preço dos escravos e, em primeira instância, o gênero e a geração; e, em segunda instância, a aptidão ao trabalho (em particular o especializado) e a possibilidade de reprodução (no caso das mulheres). Eram mais valorizados os escravos homens especializados em ofícios e em idade adulta e as mulheres adultas em idade fértil. Quanto mais novos ou velhos os cativos, menor a sua avaliação. Ademais, alguns outros aspectos, como as doenças ou os problemas físicos, também diminuíam o seu valor econômico. Para uma discussão mais sofisticada a respeito da questão, ver: Mello, "Os escravos nos inventários paulistanos", pp.83 e ss.; Juliana Garavazo, "Riqueza e escravidão no nordeste paulista: Batatais, 1851-1887" (Dissertação de Mestrado, Universidade de São Paulo, 2006), pp.173-92.

29 Daina Ramey Berry, Swing the Sickle for the Harvest is Ripe: Gender and Slavery in Antebellum Georgia, Urbana and Chicago: University of Illinois Press, 2007, p.17. 
fluenciar as práticas de casamento na propriedade era a origem africana ou crioula dos cativos. A origem dos escravos não parece ter sido fator determinante na organização dos enlaces, haja vista a parca presença de cativos africanos no plantel do Engenho Bom Intento. Embora os poucos africanos tenham procurado pela endogamia metaétnica, entendemos que o maior impacto da origem crioula ou africana no delineamento dos arranjos matrimoniais entre os cativos dessa propriedade residia, com efeito, no fato de os crioulos e as suas respectivas famílias estarem estabelecidos há mais tempo na comunidade; o que, em tese, garantiria a sua inserção em uma rede de inter-relações e um circuito de sociabilidades mais consolidado.

Os três aspectos elencados (idade ao casar, prática de um ofício especializado e origem crioula ou africana) são indicativos das condicionantes que permeavam o casamento legítimo no Engenho Bom Intento. Uma maior idade, o capital simbólico inerente à especialização em um ofício e a inserção nas redes sociais e familiares plantadas há tempos naquela propriedade ajudavam alguns escravos a demarcar o seu lugar de prestígio dentro de uma hierarquia social interna da comunidade, bem como a dinamizar seu poder de barganha junto ao senhor de fato do engenho, Januário Antônio da Silva. Eram, portanto, aspectos que acabavam por imprimir, ainda que no contexto de uma comunidade e de um grupo social específico, marcas distintivas da posição diferenciada de determinados sujeitos e famílias.

Como a historiografia referente ao tema vem demostrando, a diferenciação social entre os cativos ganhava forma, nas palavras de Sílvia H. Lara: "através de critérios que envolviam tanto a dinâmica das relações específicas que [os cativos] mantinham entre si, quanto a de suas inserções num universo mais amplo de outras relações". ${ }^{30}$ Os elementos demarcadores do seu lugar social eram, nesse sentido, complementares, e atuavam de forma articulada tanto em relação ao senhor, como em relação à própria comunidade. A trajetória do escravo Manoel Carlos pode nos ajudar a compreender, de maneira mais clara, a influência dessas sociabilidades horizontais e verticais na demarcação do lugar social dos cativos, assim como na organização dos seus casamentos na comunidade escrava do Engenho Bom Intento.

30 Sílvia Hunold Lara, Campos da violência: escravos e senhores na capitania do Rio de Janeiro (1750-1808), Rio de Janeiro: Paz e Terra, 1988, p.351. 
Em setembro de 1868, na capela da propriedade, Manoel Carlos, filho legítimo de Antônio Pedro e Francisca Libânia, contraiu núpcias com Felipa Maria das Dores, filha natural de Marcelina Maria de Nazaré. O matrimônio teve como testemunhas dois antigos companheiros de cativeiro: os forros José Joaquim e Alberto Germano. ${ }^{31}$ Especializado em calafetagem, Manoel foi um dos poucos escravos a ter acesso ao matrimônio antes dos 40 anos de idade. A prática de um ofício especializado, combinada com a sua idade intermediária e a ausência de quaisquer referências a problemas físicos ou de saúde, fizeram dele o cativo mais valorizado da propriedade. Quando do arrolamento dos escravos do Bom Intento, Manoel foi avaliado em cerca de 800 mil réis.

A análise do lugar ocupado por Manoel Carlos na hierarquia interna da comunidade escrava do Engenho Bom Intento deve levar em consideração alguns aspectos que ajudaram a tornar sua trajetória particular, diferenciando-a, em maior ou menor medida, das trajetórias de Domingos Dias e de outros cativos que tiveram acesso ao casamento na propriedade. Trata-se, em linhas gerais, de três aspectos. Em primeiro lugar, tanto Manoel como a sua irmã, Geralda, eram filhos legítimos. A condição de legitimidade evidencia sua posição social de destaque ao colocá-lo como pelo menos a segunda geração de uma família que teve acesso ao matrimônio na comunidade. Em segundo lugar, Manoel Carlos também praticava um ofício especializado que lhe garantia grande prestígio perante os demais cativos e o administrador da propriedade. Em terceiro lugar, o casamento de Manoel teve como testemunhas dois libertos. Por mais que José Joaquim e Alberto Germano muito possivelmente continuassem a integrar aquela comunidade mesmo depois de alcançarem sua liberdade, o vínculo estabelecido entre eles, Manoel e Felipa não deixava de ser vertical. Além disso, por terem estado entre os 15 cativos alforriados pelas disposições testamentárias do antigo senhor, é provável que José Joaquim e Alberto Germano mantivessem uma boa relação com Januário Antônio da Silva. ${ }^{32}$

ACMB. Livro I de Registros de Casamento do Curato da Sé de Belém, p.226(v)

32 Como testamenteiro e herdeiro universal de seu irmão, foi Januário Antônio da Silva quem, por certo, determinou quais escravos seriam alforriados. Parece-nos claro que foram libertados os cativos que mantinham relações mais próximas a ele e/ou que eram mais influentes na comunidade escrava do engenho. 
O fato de Manoel integrar uma família bem posicionada socialmente na propriedade, os vínculos e o conjunto de inter-relações que mantinha com sujeitos igualmente posicionados em lugares de prestígio na comunidade, e o capital simbólico inerente à prática do ofício mais valorizado no Engenho (o de calafate) foram, muito provavelmente, determinantes no sentido de levá-lo ao casamento legítimo, sobrepondo, inclusive, o próprio recorte geracional imposto aos homens do plantel no que respeitava à idade de matrimônio. $\mathrm{O}$ mesmo podemos dizer de sua futura esposa, Felipa Maria. Classificada como filha natural por ter nascido antes do enlace entre a sua mãe e Francisco Antônio Germano - possivelmente seu pai e irmão de Alberto, que testemunhou aquele casamento - Felipa pertencia a uma extensa rede familiar existente na propriedade que, a exemplo da família de Manoel, levou vários de seus membros ao matrimônio. É possível, aliás, que o casamento entre Manoel e Felipa tenha representado um passo no sentido de estruturar uma rede familiar ainda mais ampla entre alguns escravos do Bom Intento, ajudando não só a fortalecer o grupo, como também a demarcar e dinamizar lugares na hierarquia social interna da comunidade.

A tessitura social do Engenho Bom Intento e o conjunto de inter-relações estabelecido pelos escravos da propriedade que lhe dava forma são elementos centrais para a compreensão das práticas de casamento naquele meio social. A posição social ocupada pelos escravos na hierarquia interna da comunidade condicionava a sua ascensão ao matrimônio, possibilitando que um determinado grupo de cativos - a exemplo de Manoel Carlos e sua família - pudesse negociar com maior efetividade o seu acesso ao casamento legítimo, e relegando os demais a experimentarem a conjugalidade em uniões não legitimadas pela Igreja. O grau de complexidade desse conjunto de inter-relações era particularmente ainda mais acentuado por estar inscrito numa propriedade escrava de grandes proporções, estabelecida há décadas e que mantinha interação constante e cotidiana com vários outros segmentos sociais - dos cativos das demais propriedades a ricos escravistas, passando pela população livre e pobre, e pelos libertos da região de Bujaru.

Ao cruzarmos os registros de batismo e casamento dos cativos, com o inventário post-mortem e o testamento de Joaquim Antônio da Silva, podemos constatar que grande parte dos matrimônios envolven- 
do os cativos do Bom Intento orbitava, via de regra, em volta de uns mesmos escravos. O casamento legítimo naquela propriedade era mais comum entre algumas famílias; as mesmas que tiveram alguns dos seus membros alforriados, que concentravam um maior número de escravos com ofícios especializados e que mantinham relações estreitas seja com o administrador da propriedade, Januário Antônio da Silva, seja com sujeitos que podem ter figurado como intermediários sociais, a exemplo do que possivelmente representaram José Joaquim e Alberto Germano, já libertos, no casamento do calafate Manoel Carlos.

José Joaquim, Alberto Germano e tantos outros, em face da sua projeção na comunidade, poderiam intermediar a construção e dinamização das teias sociais existentes naquele meio social, ao colocarem em interface as redes familiares existentes e, sobretudo, ao intercederem junto ao administrador da propriedade, negociando, facilitando o acesso de determinados escravos e famílias ao casamento legítimo. A atuação desses prováveis intermediários reforça a noção de que a articulação dos matrimônios na propriedade era concebida em um jogo entre duas hierarquias sociais interpostas. Não bastava que os escravos estivessem situados em lugares sociais de destaque na hierarquia interna da comunidade. Tão importante quanto isso era a anuência de Januário Antônio da Silva.

A propósito, o papel exercido por Januário na articulação dos casamentos dos escravos do Engenho Bom Intento ganha relevo pelo fato de todos os escravos desta propriedade terem contraído matrimônio com companheiros de plantel, a despeito do amplo rol de sociabilidades no qual estavam inseridos. Como vem demonstrando a historiografia sobre o tema, por mais que os cativos provavelmente tivessem a possibilidade de escolher os seus cônjuges com um relativo grau de autonomia, dificilmente seriam legitimadas as relações que não fossem vistas com "bons olhos" pelos seus senhores. ${ }^{33}$ No caso dessa propriedade, a interferência senhorial nos enlaces foi mencionada, inclusive, nas próprias atas de casamento. Os registros referentes aos escravos do Bom Intento foram os únicos assentos que encontramos nos quais se explicitava, literalmente,

33 Referências gerais a esse debate podem ser conferidas em: Robert Slenes, “A formação da família escrava nas regiões de grande lavoura do Sudeste: Campinas, um caso paradigmático no século XIX", População e Família, v.1, n.1 (1998), pp.9-82. 
que os matrimônios aconteceram "sob a autorização do administrador da propriedade".

Não seria de todo irreal supormos que a interferência de Januário não tenha se limitado somente ao casamento legítimo e, como veremos mais adiante, às relações de compadrio estabelecidas pelos seus cativos. Se, no que respeita ao matrimônio, a intervenção senhorial é evidente (todos os escravos casaram-se, sem exceção, com companheiros de propriedade), pode ter havido uma maior flexibilidade em relação às uniões não legitimadas pela Igreja. O grande excedente de mulheres em idade fértil existente na escravaria, evidentemente não deixaria de ser notado por parte do administrador do engenho. É não apenas possível, como também provável, que Januário não criasse impedimentos para que as escravas do Engenho Bom Intento se relacionassem com cativos de outras propriedades, os forros ou os homens livres da região, desde que consensualmente. Em parte corroborando esta perspectiva, as atas paroquiais de batismo pesquisadas indicam que, entre 1840 e 1870, três de cada quatro cativos nascidos no Bom Intento foram concebidos fora do matrimônio.

Nesse sentido, na experiência analisada, as duas faces do casamento (legítima ou não) atuaram, de diferentes maneiras, no sentido de conformar uma comunidade escrava que tinha o seu epicentro no Engenho Bom Intento. Se, por um lado, o casamento legítimo acabava por reforçar lugares e dinamizar uma hierarquia social interna na propriedade, por outro lado, as uniões não legitimadas pela Igreja faziam com que a ideia de comunidade escrava transbordasse as fronteiras do engenho, compreendendo cativos de outros senhores, libertos e parte da população livre de Bujaru. Esta concepção certamente mais abrangente da noção de comunidade escrava ajuda a superar a perspectiva de que a sua formação estava relacionada apenas às bases institucionais da família no interior das propriedades, onde as relações entre senhores e escravos efetivamente se desenvolviam. Em verdade, como podemos apreender no caso em tela, o delineamento das comunidades se dava no bojo de um universo social e de inter-relações mais extenso, que não se restringia somente às relações de caráter endógeno estabelecidas pelos escravos entre si, e entre eles e os seus respectivos senhores. 


\section{Expandindo uma comunidade: o compadrio}

Assim como o casamento, o compadrio representava uma peça-chave na composição das comunidades escravas. O seu caráter simultaneamente social e religioso, ${ }^{34}$ por certo, bastante arraigado em grupos essencialmente crioulos como o do Engenho Bom Intento, fazia, do parentesco espiritual materializado nos batismos, um importante mecanismo de dinamização das ditas comunidades. ${ }^{35}$

A exemplo do que ocorria também em relação ao casamento, as práticas de compadrio dos escravos do Engenho Bom Intento aproximavam-se das tendências apresentadas pelas regiões mais afastadas de Belém, onde a alta concentração de cativos ascendia à incidência da escolha de compadres e comadres de condição escrava e, por conseguinte, à preferência pelo estabelecimento de vínculos horizontais de compadrio. ${ }^{36}$ Entretanto, por mais que grande parte deles tenha estabelecido laços de parentesco espiritual com os seus companheiros de propriedade, havia uma maior flexibilidade nessas relações, pois, diferentemente do que acontecia no matrimônio, os limites do engenho se dispunham de maneira um pouco mais elástica no caso das relações de compadrio.

Por um lado, a predileção pelas relações endógenas à propriedade implicava o fortalecimento do grupo e a possibilidade de se demarcar, com maior limpidez, os lugares sociais ocupados pelos cativos e suas famílias na hierarquia interna da comunidade. Por outro lado, abria-se possibilidade para que a interação cotidiana que os escravos do Engenho Bom Intento mantinham com os cativos das demais propriedades e a população livre da região de Bujaru se solidificasse na forma de uma relação exógena permanente, instituída pela religião e com inquestionável reconhecimento social no contexto do Brasil oitocentista.

Portanto, no caso em questão, o jogo entre diferentes estratégias atinentes à escolha dos compadres acabava dilatando os próprios limites

34 Donald Ramos, "Teias sagradas e profanas: o lugar do batismo e compadrio na sociedade de Vila Rica durante o século do ouro", Varia Historia, v.31 (2004), pp.41-68.

35 José Roberto Góes, O cativeiro imperfeito: um estudo sobre a escravidão no Rio de Janeiro da primeira metade do século XIX, Vitória: SEJC/SEE, 1993; Cacilda Machado, "As muitas faces do compadrio de escravos: o caso da freguesia de São José dos Pinhais (PR), na passagem século XVIII para o XIX”, Revista Brasileira de História, v.26, n.52 (2006), pp.49-77.

36 Barroso, "Casamento e compadrio em Belém", pp.121-43. 
da comunidade escrava constituída, que passava a abarcar, inclusive, indivíduos de condição livre. Por trás da escolha dos compadres, havia todo um conjunto de inter-relações, interesses e motivações que as norteava. Assim como, no que tange ao casamento, os laços formados eram condicionados pelo lugar social dos envolvidos. A trama de relações vivenciada pelos escravos, o grau de autonomia angariado, as necessidades momentâneas e uma evidente preocupação com o futuro das crianças batizadas eram aspectos que decerto influíam no delineamento dos laços de compadrio.

No dia 22 de fevereiro de 1846, no oratório do Engenho Bom Intento, batizou-se solenemente e recebeu os Santos Óleos a pequena Justina, filha natural da escrava Cristina Maria. Ao contrário dos dias em que havia vários batizados e matrimônios na propriedade, o batismo de Justina foi uma cerimônia isolada. Ainda assim, representou um importante momento para a socialização dos cativos diretamente envolvidos no evento: a mãe de Justina, Cristina Maria, o padrinho Conrado e a madrinha Apolinária, todos eles escravos de Joaquim Antônio da Silva. ${ }^{37}$ Quatro anos antes, no mesmo oratório, mas em meio a várias outras cerimônias de batismo e de casamento, fora batizado Teodósio, filho também natural de Luciana Maria, que teve como padrinho e madrinha dois companheiros de cativeiro de sua mãe, de nomes Agostinho e Guilhermina do Carmo. ${ }^{38}$

Muito embora os registros dos batismos de Justina e Teodósio não sejam elucidativos, por si só, dos tipos de relação que Cristina e Luciana Maria mantinham com os padrinhos e as madrinhas de seus filhos, de uma leitura preliminar deles emergem algumas questões que podem nos servir como ponto de partida. Em primeiro lugar, podemos considerar que, em ambos os casos, a escolha dos compadres e das comadres foi condicionada pelo interesse na criação de vínculos de natureza eminentemente social, uma vez que nem Justina nem Teodósio tiveram santos como padrinhos ou santas como madrinhas. Como um desdobramento disso, devemos considerar, em segundo lugar, que foram escolhidos para esses papéis quatro companheiros de cativeiro de Cristina e Luciana Maria, o que evidencia não apenas o seu já aditado interesse em firmar relações sociais, como o interesse específico em

37 Cúria Metropolitana de Belém (CMB). Livro IV de Registros de Batismo do Curato da Sé, p.24(v).

38 Cúria Metropolitana de Belém (CMB). Livro III de Registros de Batismo do Curato da Sé, p.33(v). 
estabelecê-las em meio à comunidade escrava à qual pertenciam. Estaríamos, nesse sentido, diante de duas estratégias semelhantes?

O diálogo entre os registros de batismo e de casamento dos escravos do Engenho Bom Intento e o inventário post-mortem de Joaquim Antônio da Silva abre, mais uma vez, instigantes possibilidades de análise, na medida em que confere novas dimensões às escolhas dos padrinhos e das madrinhas de Juliana e Teodósio. Essas dimensões revelam que, por trás de duas estratégias à primeira vista semelhantes, e que comungavam com as práticas de compadrio mais gerais dos escravos do Engenho Bom Intento, havia aspectos centrais que diferenciavam uma da outra.

A primeira possibilidade de análise diz respeito a uma questão geracional. A partir daquele diálogo, verificamos que, na altura do batizado de Justina, Conrado e Apolinária tinham, respectivamente, 15 e 25 anos. Agostinho, por sua vez, foi padrinho de Teodósio aos 50 anos de idade. Não conseguimos averiguar a idade de Guilhermina do Carmo; muito possivelmente, ela faleceu, ou foi vendida, entre o batizado de Teodósio e o arrolamento dos cativos do Engenho Bom Intento, por ocasião do inventário de Joaquim Antônio da Silva. No caso do batismo de Justina, foram selecionados um padrinho e uma madrinha jovens. No batismo de Teodósio, a escolha recaiu sobre um padrinho com maior idade, já velho. As distintas perspectivas geracionais que permearam a escolha dos padrinhos de Justina e Teodósio indicam que, em última instância, foram estratégias aparentemente semelhantes, mas, em verdade, norteadas por diferentes interesses e motivações.

Ao escolher Conrado e Apolinária como padrinhos de sua primeira filha, Cristina Maria manifestou uma preocupação em assegurar proteção e amparo a Justina, no decorrer de sua vida. A menor idade dos padrinhos permitir-lhes-ia, em tese, acompanhar a sua criação por um longo período de tempo, inclusive cuidando de Justina numa eventual ausência da mãe. Conrado foi escolhido padrinho ainda muito jovem, próximo da idade mínima arrogada pela legislação canônica ${ }^{39}$ Exceto se

39 De acordo com as Constituições Primeiras do Arcebispado da Bahia, homens e mulheres só poderiam servir de padrinhos a partir dos 14 e dos 12 anos, respectivamente. Abaixo dessas idades, para sê-los, apenas com Licença Especial do Bispado. Sebastião Monteiro Vide. "Livro Primeiro, Título XVIII", in Constituições Primeiras do Arcebispado da Bahia (São Paulo: EDUSP, 2010 [1707]), pp.52-4. 
pertencesse a uma família já bem situada na hierarquia da comunidade, é muito provável que haja vista a sua pouca idade, Conrado ainda não tivesse estabelecido o seu lugar na mesma. Inclusive, o fato de ser padrinho de Justina pode ter representado, para ele, um primeiro passo no estabelecimento de sua trama de inter-relações e, consequentemente, da sua posição na comunidade. Apolinária, ao contrário de Conrado, tinha a sua rede de relações mais bem consolidada. No batismo de sua filha Sabina, por exemplo, ela se tornou comadre do escravo Clementino, um dos que por mais vezes foi escolhido para padrinho ou testemunha de casamento na comunidade.

Por outro lado, a escolha de Agostinho como padrinho de Teodósio pode ser sugestiva de um interesse mais imediato, por parte de Luciana Maria, em estabelecer uma aliança com alguém de prestígio em meio à hierarquia social da comunidade. Além de uma maior idade e do fato de ele pertencer, muito possivelmente, a uma família já plantada há tempos na propriedade, Agostinho era oficial de pedreiro, ofício que provavelmente lhe conferia, adicionalmente aos outros dois aspectos, um status diferenciado em meio à comunidade cativa do Engenho Bom Intento.

Ainda que tragam à tona interesses e motivações diferentes, os batismos de Justina e de Teodósio são exemplos das duas formas pelas quais a perspectiva geracional condicionava a escolha dos padrinhos e das madrinhas na comunidade escrava do Engenho Bom Intento. Poucos foram os escravos na casa dos 30 ou dos 40 anos escolhidos como padrinhos. ${ }^{40}$ Geralmente, eram selecionados para esses papéis cativos que haviam acabado de entrar na idade adulta, tal qual Conrado e Apolinária, ou que já se enquadravam no grupo etário dos velhos, como Agostinho. Posto que o Gráfico1 advirta para uma baixa mortalidade na propriedade, a

40 A escolha de compadres mais jovens ou mais velhos pode ter estado relacionada, também, à estrutura etária da propriedade. Embora tenhamos apresentado, no Gráfico 1, somente uma fotografia dessa estrutura num dado momento, é provável que a pouca quantidade de cativos (sobretudo de homens) em idade adulta tenha sido a tônica do plantel durante todo o período pesquisado (1840-1870), com poucas variações. Ainda assim, não se diminui a importância da questão da geração no processo de escolha. Cacilda Machado, pesquisando uma região em que a distribuição etária da população escrava era bem equilibrada (São José dos Pinhais, na virada do século XVIII para o XIX), encontrou resultados semelhantes, com uma tendência a terem sido selecionados padrinhos jovens (18-25 anos). Machado, "As muitas faces do compadrio de escravos", pp.71-2. 
idade dos padrinhos, por certo, não deixou de ser uma preocupação. Entendemos que a escolha de padrinhos jovens, ainda entrando em idade adulta, espelhava a preocupação dos cativos com o futuro de sua prole, garantindo amparo e proteção até que os seus filhos pudessem estabelecer o seu lugar social por meio de inter-relações próprias. Por sua vez, a seleção de padrinhos mais velhos pode ser tomada como um indicativo de uma necessidade mais premente de consolidação das relações entre os futuros compadres.

Essas duas estratégias de escolha dos padrinhos e madrinhas de acordo com a perspectiva geracional, muito embora evidenciassem dois usos sociais distintos do compadrio naquela comunidade, não eram necessariamente opostas, podendo ser, ao contrário disso, complementares uma à outra, mesmo em relação a uma família específica. Essa interação entre as estratégias norteou os laços de compadrio conformados pela família dos escravos Antônio e Francisca, por meio dos batismos das três filhas desse casal.

Entre 1842 e 1848, Antônio e Francisca batizaram pelo menos três dos seus filhos: em 1842, Geralda; em 1844, Susana; e, em 1848, Luísa. Mesmo em condição escrava, Antônio era intendente, um dos responsáveis por supervisionar a organização produtiva da propriedade. À altura do batismo de Geralda, em 1842, ele tinha em torno de 50 anos de idade. A sua mulher, Francisca, destoando do padrão de concepção daquela comunidade, deu à luz suas três filhas entre os 30 e os 40 e poucos anos de idade. As elevadas idades do casal, sobretudo a de Antônio, certamente condicionaram a escolha dos padrinhos das suas três meninas, no que concerne à idade dos padrinhos. Não obstante, face à posição de prestígio em que o intendente se encontrava, ${ }^{41}$ ainda era necessário estabelecer relações de compadrio com indivíduos bem situados na hierarquia social da comunidade, de modo a corroborar as marcas distintivas da sua posição social.

A primeira filha batizada, Geralda, teve como padrinhos os es-

${ }^{41}$ É de pensarmos que a função de "intendente" fosse análoga à de "feitor". No entendimento de Hebe Mattos, tratava-se de um ofício que indicava a posição de prestígio de terminado escravo vis-à-vis à comunidade cativa e ao senhor. Não seriam feitores aqueles que não tivessem o respeito de ambas as partes. Hebe Maria Mattos, Das cores do silêncio: os significados da liberdade no sudeste escravista, Brasil, século XIX, Rio de Janeiro: Nova Fronteira, 1999 [1995], pp.124 e ss. 
cravos Luís e Apolinária Maria, a mesma que havia sido madrinha da pequena Justina. ${ }^{42}$ Não encontramos outras referências em relação a Luís, mas sabemos que Apolinária possuía 20 anos de idade quando do batizado de Geralda. A segunda filha do casal, Susana, foi apadrinhada por Felipe Nery e Inácia Maria. ${ }^{43}$ Não dispomos de informações mais precisas a respeito da madrinha, porém, descobrimos que Felipe Nery também veio a ser padrinho de Umbelina, a primeira filha do já citado Alberto Germano com a escrava Esperança, batizada no oratório do Engenho Bom Intento em 24 de abril de $1847 .{ }^{44}$ A terceira filha de Antônio e Francisca, Luísa, teve Carlos como padrinho e Nossa Senhora ${ }^{45}$ das Dores como madrinha. ${ }^{46}$ Assim como Guilhermina do Carmo, madrinha de Teodósio, Carlos muito provavelmente veio a ser vendido ou a falecer nos anos subsequentes, pois não marcou presença na lista dos cativos do Engenho Bom Intento elaborada por ocasião do inventário de Joaquim Antônio da Silva.

Cada um dos batismos das três filhas de Antônio e Francisca apresentou características específicas. No batismo da primogênita, Geralda, o casal priorizou a consolidação de vínculos com indivíduos mais jovens, que pudessem dar amparo a sua filha, caso porventura Antônio e Francisca viessem a falecer. No batismo de Susana, o casal provavelmente tencionou estabelecer laços com escravos bem relacionados em meio à comunidade, como Felipe Nery. Por sua vez, a escolha de Nossa Senhora das Dores como a madrinha de Luísa (não podemos tecer muitas considerações a respeito de Carlos) evidencia uma escolha assentada muito mais numa questão religiosa do que na concepção de vínculos de natureza social.

Nesse sentido, podemos observar claramente a partir dos laços de parentesco espiritual estabelecidos nos batismos das três filhas de Antônio e Francisca, ser o compadrio regido por estratégia eminentemente familiar, cuja historicidade, nos meandros da história de uma determinada

${ }^{42}$ Cúria Metropolitana de Belém (CMB). Livro III de Registros de Batismo do Curato da Sé, p.34.

${ }^{43}$ Cúria Metropolitana de Belém (CMB). Livro III de Registros de Batismo do Curato da Sé, p.115(v).

${ }^{44}$ Cúria Metropolitana de Belém (CMB). Livro IV de Registros de Batismo do Curato da Sé, p.95.

45 A escolha de Nossa Senhora como madrinha não foi expressiva em meio à comunidade escrava do Engenho Bom Intento. Detectamos apenas cinco casos em que isso ocorreu. Em dois desses casos, a escolhida foi Nossa Senhora das Dores. Nos outros três, não foi especificada.

${ }^{46}$ Cúria Metropolitana de Belém (CMB). Livro IV de Registros de Batismo do Curato da Sé, p.119. 
família, deve considerar as distintas demandas e conjunturas sociais que abalizaram a sua trajetória ao longo do tempo.

A construção dessa e de outras trajetórias familiares em meio ao Engenho Bom Intento revela o possível grau de estabilidade familiar ensejado aos cativos dessa propriedade. Se a longevidade senhorial, a dimensão da posse e a eventual inflexão proporcionada pela morte do senhor eram três dos elementos que atuavam no sentido de conceber uma maior ou menor estabilidade às famílias escravas, o engenho constituiria, pelo menos em tese, um lócus ideal para a manutenção dos laços familiares dos cativos por longo período de tempo. ${ }^{47}$ Explicamos melhor. Joaquim Antônio da Silva faleceu aos 80 anos de idade deixando praticamente todos os seus bens (exceto aqueles legados por terça testamental) a um único herdeiro: o seu irmão, Januário Antônio da Silva. Somente o fato de a propriedade não ter sido partilhada provavelmente contribuiria para essa estabilidade.

Mas, não se tratava apenas disso. Januário já administrava a propriedade (e, consequentemente, os seus cativos) desde 1834, quando seu irmão deixou em definitivo a Amazônia rumo a Portugal. Portanto, quando se tornou de fato o proprietário do Engenho Bom Intento, Januário Antônio da Silva já o geria há quase três décadas. Nesses termos, é possível que o impacto da morte do senhor tenha sido minimizado, ou mesmo, quem sabe, inexistente. Entretanto, se, por um lado, esse provável contexto de estabilidade não apenas permitia como também dinamizava a construção de extensas e duradouras redes sociais no seio da comunidade, por outro lado, isso não significa dizer que a consolidação dessas redes por meio do compadrio não passasse pela influência de Januário Antônio da Silva.

Decerto, o controle senhorial sobre os escravos do Engenho Bom Intento incidia muito mais em relação ao matrimônio do que em relação à formação dos laços de parentesco espiritual. Se, no que toca ao casamento legítimo, fazia-se respeitar, incondicionalmente, os limites da propriedade, no caso do compadrio esse controle se efetivava de maneira

47 Sobre a estabilidade possível das famílias escravas, cf.: José Flávio Motta e Agnaldo Valentin, "A estabilidade das famílias em um plantel de escravos de Apiaí (SP)", Afro-Ásia, v.27 (2002), pp.161-92; Robert Slenes, "Escravidão e família: padrões de casamento e estabilidade familiar numa comunidade escrava (Campinas, século XIX)", Estudos Econômicos, v.17, n.2 (1987), pp.217-27. 
menos incisiva. A procura por compadres fora do engenho evidencia que o parentesco espiritual era supostamente mais "independente" da ingerência senhorial do que o matrimônio, por mais que as sociabilidades dos escravos certamente não deixassem de ser controladas. ${ }^{48}$

Grande parte da historiografia que se dedica ao compadrio de escravos indica que a presença senhorial fazia-se sentir pelo menos enquanto um limitante. ${ }^{49}$ No caso do Engenho Bom Intento, onde os batismos ocorriam em cerimônias coletivas que envolviam, para além dos escravos do próprio Bom Intento, os de outras propriedades e a população livre da região, é difícil imaginarmos um Januário totalmente alheio a essa movimentação nas terras que administrava.

Os assentos de batismo não são claros no sentido de sugerir a interferência de Januário nos laços de compadrio formados entre os escravos do Engenho Bom Intento. Evidentemente, isso não implica a inexistência de intervenção senhorial nessas relações. As sociabilidades dos escravos formalizadas pelos laços de compadrio eram sem dúvida acompanhadas de perto por Januário Antônio da Silva ou por alguém da sua mais inteira confiança, como tudo o que era importante para os seus cativos. Por mais que pudesse não se tratar, como no caso dos matrimônios, de uma ingerência direta, essa injunção fazia-se presente ainda que de maneira tácita, mesmo sobre as situações aparentemente mais "independentes".

Por outro lado, a ingerência senhorial torna-se bem mais manifesta

48 Algumas hipóteses podem ser levantadas a respeito desses diferentes graus de controle. A mais importante delas, a nosso ver, é atinente à estabilidade familiar possibilitada pelo matrimônio. Uma vez casados perante a Igreja, a eventual separação dos escravos de seus cônjuges e sua prole passava a ser dificultada, até ser definitivamente proibida, por decreto, no final dos anos de 1860. Cf.: Código de Leis do Império do Brasil (CLIB). Decreto 1695 de 15 de setembro de 1869.

49 Por mais que se reconheça certa dose de autonomia dos cativos na escolha dos compadres, a historiografia que se dedica ao compadrio admite, quase que unanimemente, a ingerência senhorial nesse processo. Dentre outros, comungam com essa perspectiva: Robert W. Slenes, $N a$ senzala, uma flor: esperanças e recordações na formação da família escrava - Brasil Sudeste, século XIX, Campinas: Editora da Unicamp, 2011 [1999]; Stuart B. Schwartz, “Abrindo a roda da família: compadrio e escravidão em Curitiba e na Bahia", in Stuart B. Schwartz, Escravos, roceiros e rebeldes (Bauru: EDUSC, 2001 [1992]), pp.263-92; Cacilda Machado, A trama das vontades: negros, pardos e brancos na construção da hierarquia social do Brasil escravista, Rio de Janeiro: Apicuri, 2008; Carlos de Almeida Prado Bacellar, "Criando porcos e arando a terra: família e compadrio entre os escravos de uma economia de abastecimento (São Luís do Paraitinga, Capitania de São Paulo, 1773-1840)", Anais do $3^{\circ}$ Encontro Escravidão e Liberdade no Brasil Meridional (Florianópolis: Universidade Federal de Santa Catarina, 2007). 
nos casos em que a escolha dos compadres extrapolava os limites da propriedade, configurando-se o estabelecimento, ou ainda, a ritualização de relações exógenas ao seu ambiente, seja com cativos das propriedades vizinhas ou com a população livre de Bujaru. Essa escolha exógena perpassava, assim como o matrimônio, pelo imbricamento entre a esfera dos escravos e a esfera senhorial. A nosso ver, é pertinente considerarmos que os cativos tivessem plena consciência dos indivíduos com quem poderiam estabelecer laços de compadrio, sem que a escolha tivesse que acabar sendo, por assim dizermos, vetada por Januário Antônio da Silva.

Dois aspectos são sugestivos dessa consciência. Em primeiro lugar, é provável que os escravos soubessem que, no oratório do Engenho Bom Intento, apenas seriam realizados batismos e casamentos com a autorização de Januário Antônio da Silva, isto é, com pessoas cuja presença sua ou de seus proprietários não desgostasse Januário. Sendo, essas cerimônias coletivas, importantes espaços de socialização dos escravos do Bom Intento com os sujeitos externos ao ambiente da propriedade, ampliava-se o leque de possibilidades para a seleção dos compadres. Em segundo lugar, também é razoável pensarmos que os escravos tivessem ciência, mesmo que superficialmente, das relações entre Januário e os demais escravistas de Bujaru. Afinal, não esqueçamos que, no próprio oratório do Bom Intento, ele costumava apadrinhar os filhos e os netos dos proprietários das terras vizinhas. ${ }^{50}$

A utilização do testamento e do inventário post-mortem de Joaquim Antônio da Silva, em complementaridade aos registros batismais e de casamento dos seus escravos, potencializa o mapeamento dos vínculos que foram, de fato, exógenos àquele ambiente. Nesse sentido, por meio do diálogo entre os diferentes tipos de fonte, suprimos parte das limitações relacionadas com os assentos de batismo de Belém no que concerne à condição sociojurídica dos padrinhos. Uma investigação calcada apenas nos assentos paroquiais poderia nos levar a conclusões precipitadas sobre alguns dos laços formados pelos escravos do Engenho Bom Intento. Caso interessante é o do forro Veríssimo.

Durante os anos de 1860, Veríssimo foi responsável por testemunhar e servir de padrinho em algumas cerimônias de casamento e batismo

${ }_{50}$ Cúria Metropolitana de Belém (CMB). Livro IV de Registros de Batismo do Curato da Sé, p.13. 
de escravos do Bom Intento. O testamento e o inventário de Joaquim Antônio permitiu-nos ter ciência de que o forro havia sido, na verdade, escravo dessa propriedade, tendo sido libertado pelas disposições testamentárias do antigo senhor. A recorrência ao seu nome nos registros paroquiais sugere que, mesmo após a concessão de sua alforria, Veríssimo não se distanciou da comunidade. Considerando-se tão somente os assentos paroquiais, ele seria fatalmente tomado como um sujeito que, haja vista a sua (nova) condição social, não pertencia ao ambiente da propriedade; quando, diferentemente disso, tratava-se de um membro da comunidade, onde há tempos exercia o ofício de carpinteiro.

Para Veríssimo, Alberto Germano e outros tantos egressos do Engenho Bom Intento, a experiência da liberdade e a nova condição social que lhes foi adjudicada por meio da alforria não implicaram o seu afastamento da comunidade cativa da propriedade. A recursiva presença desses indivíduos no papel de testemunhas de casamento e de padrinhos de batismo pode insinuar, inclusive, que eles tenham permanecido como agregados no engenho. Muitas hipóteses podem ser elencadas para explicar o porquê dessa possível permanência. A nosso ver, a principal hipótese é atinente aos vínculos familiares que os forros estabeleceram no ambiente da propriedade. Embora Alberto, por exemplo, tenha sido alforriado, a sua família não o foi. Tanto a sua esposa Esperança quanto a sua filha Umbelina permaneceram no cativeiro, como indica o inventário de Joaquim Antônio da Silva. ${ }^{51}$

Não encontramos muitas referências ao compadrio exógeno na experiência analisada. Como já destacamos, ao contrário do que ocorria no núcleo urbano de Belém, a maior dimensão da propriedade proporcionou que a maioria dos laços de compadrio estabelecidos pelos escravos do Bom Intento se remetesse a companheiros de cativeiro. A dimensão da

${ }^{51}$ A alforria não suprimia, instantaneamente, os vínculos sociais que os agora libertos possuíam com o seu antigo cativeiro. Em nosso estudo acerca do casamento e do compadrio de escravos na Belém oitocentista, encontramos diversos casos em que forros casaram-se ou tornaram-se compadres de antigos companheiros de propriedade. Naturalmente, não eram em todas as situações que os libertos permaneciam tão ligados ao antigo cativeiro, como no caso de Veríssimo e Alberto Germano. Cabe-nos destacar que, para Veríssimo, já viúvo, a especialização em um ofício poderia facilitar a sua inserção no mercado de trabalho assalariado, conferindo-lhe ainda maior projeção social. Barroso, "Casamento e compadrio em Belém". Sobre as trajetórias de projeção social dos forros, ver especialmente: Roberto Guedes, Os egressos do cativeiro: trabalho, familia, aliança e mobilidade social (Porto Feliz, São Paulo, c.1798- c.1850), Rio de Janeiro: Mauad/FAPERJ, 2008. 
posse ofertava aos escravos um rol maior de possibilidades de escolha de padrinhos e compadres em seu próprio meio, distintamente do que ocorria na região central de Belém, marcada por pequenas posses e pelo inevitável convívio cotidiano entre escravos e a população livre.

Um dos únicos casos concretos, nesse sentido, foi o batizado de Miguel, filho da cativa Lúcia, ocorrido no oratório do Engenho Bom Intento em 4 de junho de 1848. Miguel teve como padrinho ninguém menos que Manoel Joaquim Pinto de Paiva. ${ }^{52}$ Proprietário das terras vizinhas ao Bom Intento, Manoel era também compadre de Januário Antônio da Silva. Não sabemos ao certo o que motivou a firmação desse laço; porém, parece-nos claro que o mesmo ocorreu sob a evidente anuência de Januário. Como já frisou Carlos Bacellar em relação a um caso semelhante: "não seria de todo irreal supor que seus senhores interferiam, até para facilitar as coisas, abrindo as portas, fazendo de seu compadre um compadre de seu cativo, implementando redes de solidariedade mais complexas". ${ }^{53}$ Lúcia mantinha, provavelmente, uma relação estreita com Januário Antônio da Silva, pois, além de ser comadre de um compadre seu, esteve entre os 15 escravos por ele alforriados. Somos levados a crer, inclusive, que Januário Antônio da Silva lançou mão do batismo de Miguel para estreitar ainda mais os laços que mantinha com Manoel Joaquim Pinto de Paiva.

A escolha de padrinhos mais bem posicionados socialmente, como Manoel Joaquim Pinto de Paiva, acabava por constituir um importante mecanismo de reprodução social, em termos diferentes do que foi o casamento legítimo naquela comunidade. A assimetria social entre as partes, responsável por atribuir um caráter verticalizado às relações estabelecidas, contribuía para reiterar a posição social dos envolvidos e suas famílias, ainda que suprimindo a pretensa ideia de igualdade existente entre os compadres. ${ }^{54}$

Ao lado do casamento, o compadrio consubstanciava a ideia de uma comunidade cativa em meio aos escravos do Engenho Bom Intento, cujos limites transcendiam as fronteiras da propriedade e do próprio cativeiro. Servia, portanto, como um importante elemento de constituição e dinamização de redes sociais dentro e fora da própria comunidade.

52 Cúria Metropolitana de Belém (CMB). Livro IV de Registros de Batismo do Curato da Sé, p.134.

53 Bacellar, "Criando porcos e arando a terra", p.6.

54 Machado, A trama das vontades, p.199. 


\section{Considerações finais}

O Engenho Bom Intento serviu-nos, nas últimas páginas, como um pano de fundo para o empreendimento de um novo esforço de investigação das relações e das experiências familiares dos escravos no Grão-Pará oitocentista. Afastando-nos do enfoque serial que delimitou as pesquisas anteriores sobre a família escrava no contexto historiográfico paraense, optamos por percorrer o caminho da microanálise das práticas de casamento e compadrio dos cativos dessa propriedade. A redução da escala de observação ensejou-nos adentrar mais amiúde no universo daquelas relações e experiências, ajudando a matizar sua compreensão na direção de aspectos que, muito provavelmente, acabariam invisibilizados numa abordagem de caráter quantitativo. Mais do que números e padrões de comportamento, objetivamos delinear práticas sociais e as lógicas de ação daquela comunidade, no que diz respeito ao casamento e ao compadrio.

Na primeira seção do artigo, voltamo-nos a apresentar o perfil e parte dos mecanismos de reprodução dos escravos do Engenho Bom Intento, assim como a estrutura física e econômica dessa propriedade. Em síntese, buscamos tracejar as características gerais da vida social e material desses cativos, de maneira a possibilitar o entendimento das formas pelas quais as famílias se constituíam, arranjavam e reproduziam naquela comunidade. Se, por um lado, a vida material ocupava lugar de proeminência na sua organização (demarcando os períodos em que ocorriam os batizados e os casamentos, a posição dos cativos na hierarquia social da comunidade, etc.), por outro lado, a vida social dos escravos, dinamizada pela permanente interação com pessoas livres e com os escravos de outras propriedades, fazia das relações familiares dos cativos do Engenho Bom Intento experiências multifacetadas.

Na segunda seção, articulando casos particulares às práticas de casamento da propriedade e às tendências de casamento de escravos na cidade de Belém, verificamos que os escravos que legitimaram suas uniões nessa propriedade apresentavam algumas especificidades. Os homens eram, em geral, maiores de 40 anos e especialistas em um ofício; já as mulheres casavam-se em idades variadas. Verificamos também que parte dos noivos era de condição legítima e pertencia a famílias muito provavelmente estabelecidas na comunidade há algum tempo. Todos 
esses elementos, analisados conjuntamente, levaram-nos a apreender que o acesso ao casamento passava, na experiência analisada, pelos escravos e suas famílias numa hierarquia social endógena à comunidade, que se plasmava tanto pelas relações que os cativos mantinham entre si, como pelas que mantinham com o senhor de fato do Engenho Bom Intento, Januário Antônio da Silva.

Na terceira seção, observamos que assim como o casamento, o compadrio era enviesado por uma clara perspectiva geracional, não apresentando diferenciações quanto ao sexo ou à condição de legitimidade dos batizandos. Algumas vezes, buscavam-se como padrinhos indivíduos com uma menor idade, que poderiam acompanhar os escravos em um mundo marcado por uma alta mortalidade. Em outras, procurava-se por compadres com maior idade, especializados em algum ofício e bem situados na hierarquia interna da comunidade. Menos passíveis de ingerência senhorial do que o matrimônio, entretanto ainda limitados pelas vontades e pelas relações mantidas pelos escravos com Januário, os laços de compadrio constituíram um elemento-chave para a compreensão de uma comunidade escrava nessa propriedade, que extrapolava os próprios limites do plantel, abarcando livres, forros e cativos de outras posses.

Fossem esporádica, consensual ou legítima as formas pelas quais se constituía e reproduzia, a família escrava era uma realidade presente em meio à comunidade cativa do Engenho Bom Intento. É muito provável, ademais, que tenha sido uma realidade fortemente presente na região de Bujaru, bem como no restante da província do Grão-Pará. O grau de incidência, os modos de organização, reprodução e sua estabilidade possível na região ainda carecem de novos estudos que tenham nela, a família escrava, o seu eixo central de análise.

Recebido em 20 de junho de 2012 e aprovado em 16 de agosto de 2013 


\title{
Resumo
}

Este artigo tem como objetivo ajudar a matizar a compreensão em torno da família escrava no Grão-Pará oitocentista, a partir da análise das práticas de casamento e de compadrio da escravaria do Engenho Bom Intento. A propriedade do português Joaquim Antônio da Silva, situada no Distrito de Bujaru, na Comarca de Belém, destacava-se por toda a sua importância econômica local e grande plantel, composto por mais de 150 cativos no limiar da década de 1860. Procura-se delinear as tendências de casamento e de compadrio desse grupo - confrontando-as com os padrões de comportamento apresentados pela população escrava de Belém —, assim como, evidenciar a atuação conjunta do casamento e do compadrio na conformação de uma comunidade escrava que extrapolava os próprios limites do cativeiro, compreendendo escravos de outras propriedades e, ainda, os forros e diversos outros segmentos da população livre da região.

Palavras-chave: Família escrava - casamento - compadrio - Grão-Pará - século XIX.

\begin{abstract}
In order to better organize the understanding of the slave family in Grão-Pará, in the $19^{\text {th }}$ Century, this paper aims to analyze the practices of marriage and compadrazgo of the slaves of the Engenho Bom Intento. The property of Joaquim Antônio da Silva, situated in the district of Bujaru (near Belém), stood out for its great local economic importance and its great slaveholding, composed of more than 150 slaves (65 men and 77 women) at the time of the 1860s. The main objective of this paper is to delineate the patterns of marriage and compadrazgo at that property, comparing them to the patterns of marriage and compadrazgo of slaves in Belém as a whole; as well to investigate the conformation of a slave community that went beyond the limits of that captivity, covering also the slaves of other properties, the freed slaves, and the free people in Bujaru.
\end{abstract}

Keywords: Slave family - marriage - compadrazgo - Grão-Pará - nineteenth century. 